\title{
Influence of Technology and Environment on the Pollen Germination Capacity in Cherry
}

\author{
Andreea Flavia ANDRECAN ${ }^{1 *}$, Viorel MITRE ${ }^{1}$, Olimpia IORDĂNESCU ${ }^{2}$ and \\ Mirela Irina CORDEA ${ }^{1}$ \\ University of Agricultural Sciences and Veterinary Medicine, Cluj-Napoca, Advanced Horticultural \\ Research Institute of Transylvania, 3-5 Mănăş̦tur St. Cluj-Napoca, Romania \\ ${ }^{2}$ Department of Fruit growing, University of Agricultural Sciences and Veterinary Medicine of \\ Banat,"King Mihai I of Romania , Timisoara \\ *corresponding author: andreaflavia_tripon@yahoo.com
}

Bulletin UASVM Horticulture 75(2) / 2018

Print ISSN 1843-5262, Electronic ISSN 1843-536X

DOI:10.15835/buasvmcn-hort: 2018.0040

\begin{abstract}
Pollen of four cherry cultivars ('Lapins, 'Kordia,' 'Sylvia,' 'Regina') was collected and examined with microscop to determine its germination capacity. It was observed that pollen fertility varied from $18.7 \%$ to $80.1 \%$. Environmental conditions of the studied area as well as applied treatments affected pollen germination capacity. Due to the high maximum temperature recorded in 13.03.2018, bud formation was induced 18 day earlier than in the previous years, growth started on March $31^{\text {st }}$, when the temperature was $21.5^{\circ} \mathrm{C}$. Regarding production, the highest yield was obtained in 'Regina' variety $9.7 \mathrm{~kg} /$ tree, 'Kordia' $9.3 \mathrm{~kg} /$ tree, 'Lapins' $8.8 \mathrm{~kg} /$ tree and Sylvia 8.2 $\mathrm{kg} / \mathrm{tree}$. In autumn of the previous year, the trees were fertilized with urea, in a concentration of $3 \mathrm{~kg}$ per ha, and in the spring with CROPAID, in a concentration of 5 liters per ha. The results show that germination percentage was much higher in the pollen collected from the treated trees than in the untreated ones.
\end{abstract}

Keywords: cherry, cultivars, germinability, pollen

\section{Introduction}

Sweet cherry is a fruit tree with high economic importance, due to the nutritional, commercial and technological value of the fruits. Being the first fresh fruit of the year, with a high content of vitamins, mineral salts, sugars and other nutrients cherries are one of the most valuable fruits. There are also some other early fruits, starting with the second half of May until July, without competing with other fruit tree species. As previous studies show, pollen germination capacity depends on various conditions, like environmental factors, or fertilizer management would be more appropriate of species and varieties grown (Cordea, 2014; Ercisli, 2007; Zheng et al., 2016).

\section{Aims}

The main objective of this study was to investigate pollen germinability of some sweet cheery cultivars grown in the environmental conditions of Cluj-Napoca city, in 2018.

\section{Materials and Methods}

The experiment was carried out in SC FERMA STELUȚA SRL Cluj Napoca, in a recently established orchard, in 2011. Trees were planted at $4 \mathrm{~m}$ distance between the rows and $1.5 \mathrm{~m}$ between trees in a row, getting a high density of 1666 trees/ha. The plantation has been equipped with a fertilization system with automatic programming and anti-hail support system. In autumn the trees were fertilized with urea, and in spring with CROPAID (natural plant antifreeze). The tree canopy was manipulated according to Zahn Spindel tehnique. Varieties planted were: 'Lapins', 'Kordia', 'Sylvia' and 'Regina', grafted on Gisella 5 rootstock. Flowers were collected in April, before 
Table 1. Germinability percentage of studied varieties

\begin{tabular}{cc}
\hline Variety & Germinability percentage (\%) \\
\hline GerLapins with treatment & $69.3 \%$ \\
\hline Lapins without treatment & $24.1 \%$ \\
\hline Kordia with treatment & $58.1 \%$ \\
\hline Kordia without treatment & $32.5 \%$ \\
\hline Sylvia with treatment & $32.6 \%$ \\
\hline Sylvia without treatment & $18.7 \%$ \\
\hline Regina with treatment & $80.1 \%$ \\
\hline Regina without treatment & $27.8 \%$ \\
\hline
\end{tabular}
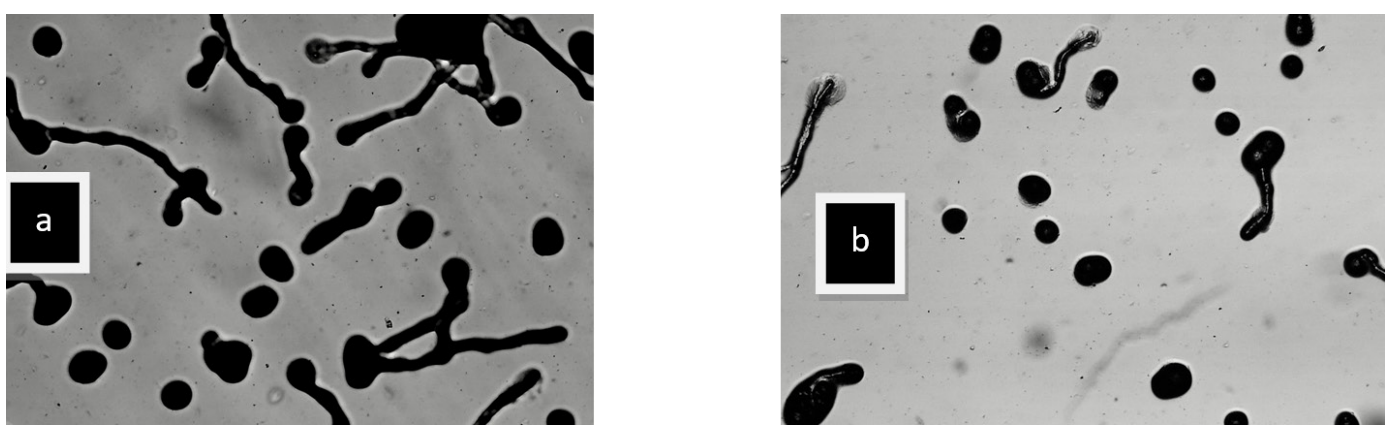

Figure 1. Pollen grain germination of 'Regina' cherry cultivars with treatment (a) and without (b) treatment (source: original), microscope magnification 10X
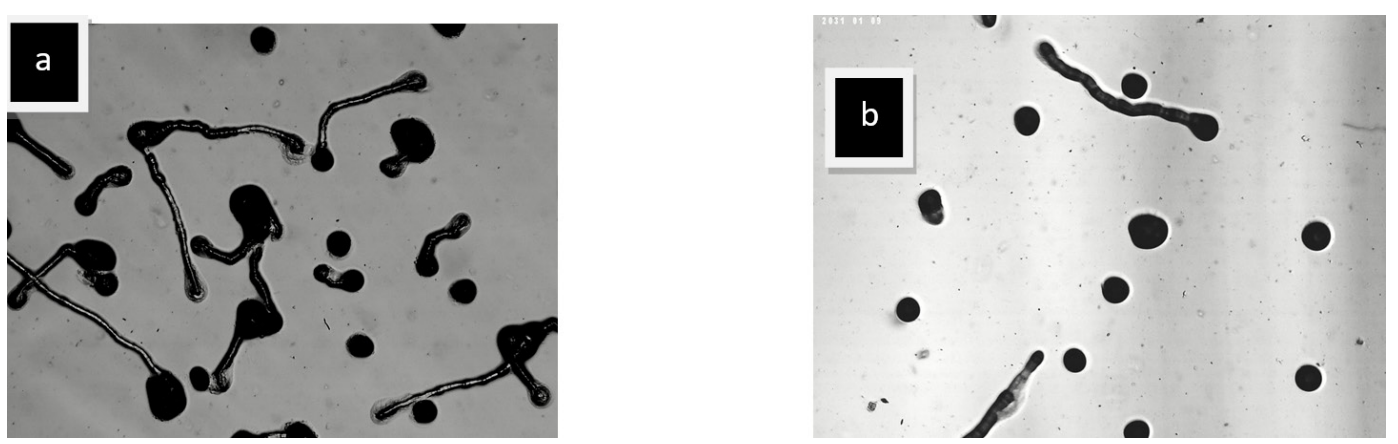

Figure 2. Pollen grains germination of 'Sylvia'cherry cultivars with treatment (a) and without (b) treatment, (source: original), microscope magnification $10 \mathrm{X}$

opening, from 10 trees of each cultivar, of each variety obtaining a petri box of pollen.

\section{Results and Discussion}

Pollen germinability in the four cherry varieties tested under pedoclimatic conditions of Cluj-Napoca was different. The viability rate varied from $18.7 \%$ to $80.1 \%$. The highest percentage of viability was recorded in 'Regina' variety while the lowest percentage of viability was observed in 'Sylvia' variety (Tab. 1).

In trees where no treatments have been applied, a low percentage of germination can be observed which leads to a low percentage of fruit binding, thus affecting fruit production. 


\section{Conclusion}

The results of the present experimental work have led to the conclusion that environmental conditions and applied treatments (urea and CROPAID) affected positively pollen germination capacity. As consequence of the treatments applied, both the germination percentage and the fruit binding percentage had higher values.

\section{References}

1. Cordea, M I (2014), Ameliorarea plantelor horticole: lucrari practice, Ed. AcademicPres Cluj-Napoca.

2. Ercisli S (2007). Determination of pollen viability and in vitro pollen germination of Rosa dumalis and Rosa villosa. Bangladesh Journal of Botany, 36(2), 185-187.

3. Zheng X, Yue C, Gallardo K, Mccracken V, Luby J and Mcferson J (2016). What attributes are consumers looking for in sweet cherries? Evidence from choice. 